ENVIRONMENT

\section{Birds and Pollution}

A CALL for more basic research on pesticide metabolism in the body and for standardization of measurements of pesticide residue was made last week at a conference held under the auspices of the British Ornithologists Union, the British Trust for Ornithology and the Royal Society for the Protection of Birds.

Sir Frank Fraser Darling and Dr Duncan Poore, joint chairmen of the conference, both emphasized the importance of birds as sensitive indicators of environmental conditions, which made their study even more important at a time when man's various activities encroach more and more on the environment. This theme was expanded by $\mathrm{Dr}$ Robert Risebrough of the Canadian Wildlife Service, who said that coastal and marine birds seem particularly vulnerable to interference by the persistent organochlorines, which include DDT and its derivatives, and the polychlorinated biphenyls (PCBs).

DDT and PCBs, said Dr Risebrough, are now distributed throughout the world and small amounts of DDT have been found in penguins and in oceangoing birds in areas far from direct sources of pollution. The amounts of DDT and PCBs found in the environment are not high enough to be directly toxic to adult birds, but these pesticides accumulate in body fat and lead to the failure of some birds, notably the brown pelican and the peregrine, to reproduce. Dr Risebrough ascribed the reproductive failure of the brown pelican colony on Anacapa Island, off the Californian coast, in 1969-72 to excessive eggshell thinning caused by extensive DDT pollution from a Los Angeles factory, which in 1970 was discharging $500-1,000 \mathrm{lb}$ of DDT daily into the sea.

Dr W. R. Bourne, from the University of Aberdeen, reported the distribution and movement surveys of seabirds around the coast of Britain during the past decade. Oil pollution was an especial hazard to the swimming birds, but gulls and waders were less affected. Oil damage seemed to be higher during January, February and March. Dr Bourne also reported that the population of auks, especially puffins, is decreasing, but the gull, fulmar and gannet populations are increasing. Discussing the proposed development of the oilfield off the north of Scotland, he thought that the greatest danger would come from disturbance of hitherto inaccessible habitats by road building and development rather than from largescale oil pollution.

Dr N. W. Moore, of Monks Wood Experimental Station, pointed out that temperate and tropical regions present different problems, as in warmer climates a greater use of pesticides is an economic necessity. In Britain, with its temperate climate, crops can be grown economically with the minimum use of insecticides, and the chief danger is from fragmentation of habitat because of the pressure on land. In North America, on the other hand, where agriculture has been concentrated into regions with intensive use of agricultural chemicals, pollution is a greater danger.

Dr J. J. M. Flegg, of the British Trust for Ornithology, called attention to the need for more research into the effects of natural factors such as climate, as well as the effects of urbanization and the loss of marshy and water habitat. Reproduction can be very variable, he said, and responses to changes are usually so delayed that by the time the effects have been recognized it is too late to apply any remedy.

Dr Duncan Poore, of the Nature Conservancy, said that serious conservationists face the dilemma that if positive proof of adverse effects is needed before action is taken, then it is usually too late to rectify the situation. So, asked Dr Poore, should action be taken on the facts in hand if an adverse effect is merely suspected?

\section{ARC \\ Annual Repon}

Nor surprisingly, in view of the publicity accorded the affairs of the Agricultural Research Council during the past year, the council's annual report for the year ended March 31, 1972, published last week (HMSO, £0.47), contains little that is new.

The year, according to the report, has been one of uncertainty under the threat of Lord Rothschild's axe and the report restates what the council emphasized during the debate on the government green paper on research and development, that priorities in applied research must "be assessed in consultation with the real customers (farmers, growers, food industrialists), scientists, economists and agricultural departments". The structure of the ARC, the report continues, was specially designed to plan and coordinate research, and offers "a ready made forum for the continuing dialogue urged by Lord Rothschild".

The government's decision on the ARC's future, made in July, will result in $£ 5$ million of the council's budget being transferred next April to the Ministry of Agriculture, Fisheries and Food, with a further $£ 2.5$ million being transferred on April 1, 1974, and a similar amount in 1975. These figures, based on 1971-72 prices, will remove more than half of the council's budget, but are less than the 78 per cent which
Lord Rothschild recommended should be transferred to the ministry.

In 1971-72 the council spent the full $£ 19.96$ million allocated to it by the Department of Education and Science, which is 16.6 per cent more than it received in 1970-71. But once inflation is allowed for, this increase becomes a more modest 5 per cent. The council also had receipts of $£ 889,711$, mostly from the sales of livestock and produce, and contributions from government departments and the Meat and Livestock Commissions. More than 50 per cent of the budget was spent in grants to independent research institutes- 2 per cent more than in 1970-71-whereas research institutes and units of the council received a slightly smaller slice of the cake-their share dropped from 28.9 per cent to 28.3 per cent. Capital expenditure also decreased in 1971-72 from 14.7 per cent of the total grant compared with 16.4 per cent in the previous year.

\section{MEDICINE \\ Developing Countries}

MONEY spent on medical care in underdeveloped countries should be put to better use, according to an Office of Health Economics report published this week (Medical Care in Developing Countries, OHE, 1972). Statistics that show the numbers of doctors per head of population are deceiving, says the report, in that they do not take into account how the medical facilities are distributed between towns and rural areas.

The statistics also give no guide to how appropriate the services are to the community. The report claims that the building of prestige hospitals gives no benefit to the mass of the population and that a better way of spending the money would be to train medical auxiliaries to practise among the rural communities. The report says that the "barefoot doctors" of China are a suitable model for other countries to copy. It is estimated that the cost of training a doctor in a hospital in the Cameroons is $£ 7,000$, and a nurse $£ 1,500$, but a medical auxiliary can be trained for only $£ 200$.

The report also comes out in favour of health centres. The $£ 2.3$ million spent on one hospital could be used to build a hundred or so medical centres that would give better service to the 70 per cent of the population of the developing countries which lives in rural areas.

Medical care, however, is not the complete answer and the availability of pure water to a community is far more significant. Also the report says that it is important to educate the population in hygienic methods of sewage disposal in order to reduce infection. 